\title{
The rise and fall of my research career
}

\section{Manfred Teichler}

Correspondence:

Manfred Teichler MD

Kruft 11

CH-9425 Thal

manfred.teichler@hin.ch

\section{Research is a bloody serious matter!}

My research career came to an abrupt end at a high level. I think it was at about 1500 meters. My friend, Tim Noakes, was visiting from Cape Town and we were hiking in the Swiss Alps. It was springtime, the weather was fine, the alpine flora breathtaking. It was then that I decided to ask him about the research I was thinking of doing. He had been a researcher all his life and could give me some free advice. It was to be my last study, sort of just before booking into the old age home.

It concerned the use of salt water gargle as a prophylactic against the common cold. I have used it over the years: as soon as viruses announce their arrival by scratchiness in my throat, I take a cup of warm water, add 3 teaspoons of salt and gargle $3 \times$ a day for 3 days. The viruses either die or depart. No cold. Well, almost always. I wanted to let the medical world share in this discovery by proving my hypothesis by research. What could be easier than testing the

\section{Figure 1}

Tim Noakes and the ex-researcher during a walk through the Ou Kaapse Weg Nature Reserve in Cape Town.

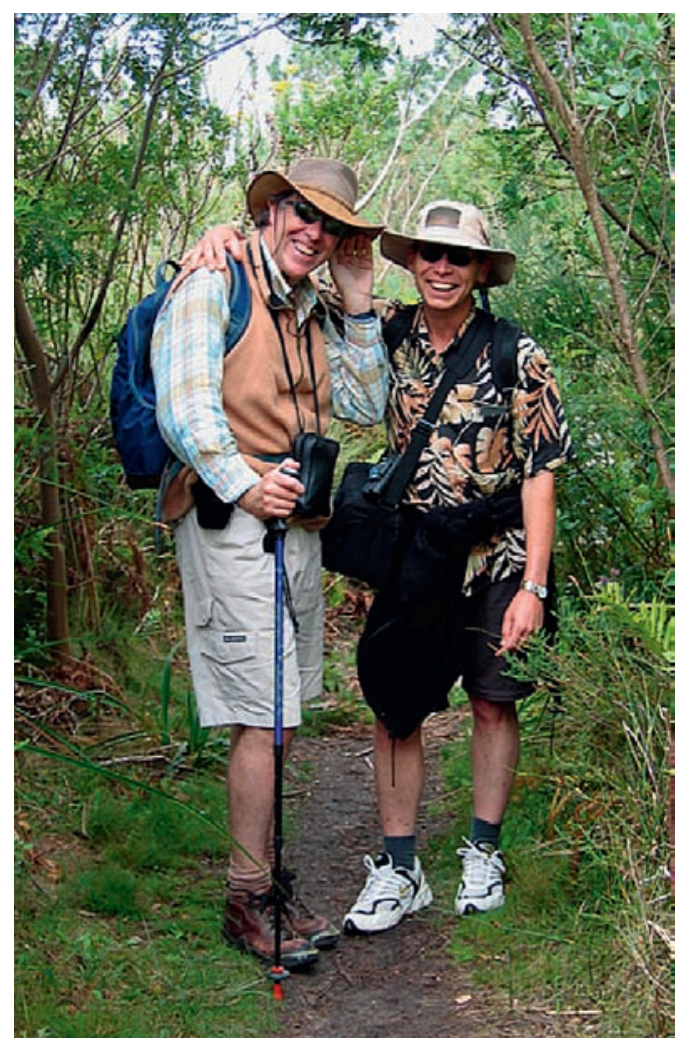

efficacy of gargling salt water? I could already imagine newspaper headlines: "Village GP conquers common cold". And a trip to Oslo would certainly solve my pension problems.

But Tim's reaction took me by surprise. There was what you might call an abrupt change of thinking cap, metaphorically speaking. He had what you might call a Swiss holiday cap on, complete with Swiss flag, Edelweiss and "I love Switzerland" on. He changed it to a rigid black research top hat, on which is written: "Research is a bloody serious matter!" He rattled off a catalogue of questions, of which I can only remember a few: 1. What would happen if they swallow this toxic mixture? 2. What is your gold standard to which you compare your treatment? 3 . What organism are you treating? Rhinovirus, influenza virus or Streptococci? ... I forgot the rest.

As abruptly as he had changed his thinking cap, he reverted back to normal. We enjoyed the fragrant alpine air, the singing of birds and blue sky and sunshine and reminiscing about our student days and our running together: round the Cape Peninsula on weekends, the Stellenbosch Marathon and finally the Comrades Marathon from Pietermaritzburg to Durban in 1973.

But it made me think. And I decided: this research is for the birds and too much sweat. I will stick to doing my GP thing.

\section{A stretcher and two white coats plus syringes}

Over the years I have been involved in various research projects. There was the tuberculosis study in the Transkei, where I lived in a VW Combi for three weeks in the remote Bulungula on the wild coast. It was top quality as far as adventure was concerned. Otherwise I don't want to talk about it. There was the care group study in Venda. A whole team of people helped me. Not to forget the lipid study I was involved in as a student. They infused a white lipid solution intravenously, then injected Insulin and observed what happened. Not much happened with me, except I was lights out for a few seconds from hypoglycaemia. The volunteer after me had a convulsion, after which the study was stopped.

Tim and I did a study in our final year at medical school. There was a 24-hour race in the Greenpoint Athletics stadium and he wanted to find out what happened to these athletes bio- 
chemically. I offered to be research assistant No. 1. Our equipment consisted of: a stretcher and two white coats, plus syringes for taking blood. Our research subjects were running round and round the athletics track. So all we had to do was sit and wait, until somebody decided to quit. We then ran to this person and asked permission to take a wee bit of their blood. They would lie down on the stretcher for the procedure.

The leading athlete was Jorrie, whom we knew well. He ran for the full 24 hours. When he approached the 24-hour time, he seemed to go berserk: he started running like crazy. When the bell rang to indicate that time was up, he continued to sprint. This is where the research team saw action. If Jorrie was running to avoid having blood taken, he was mistaken. Nobody can outrun the Noakes/Teichler team - not if that person had just run for 24 hours! So we grabbed the stretcher and gave chase with our white coats flapping in the breeze. We caught up with him on the corner closest to the harbour. He collapsed. We approached respectfully, like vultures who knew that you need patience before a meal. He indicated that we should wait. There were emotional scenes as he was reunited with his wife. Then came the shock: Jorrie did not want us to take his blood! We couldn't believe it: we had waited 24 hours, and now this! It is tough being a researcher.

\section{$\mathrm{CuSO}_{4}$ and its effects on the libido}

But my first research project was never published. What you read here is a world premiere. I think it is what they call a "seminal study". Maybe not.

It was almost exactly 40 years ago: October 1968. I was a matric student at the Hermannsburg boarding school near Kranskop, on the edge of the Tugela Valley in Natal. We were preparing for our final examination. Our brains and senses were tuned to top performance. It was the time of the year where the Christmas (Cicada) beetle was singing loudly from the trees and the air was scented from the Blackwattle forests around us. In the valley below the school the arum lilies were flourishing in the marshy soil around the Hlimbitwa stream, making a beautiful white show with their elegant long-stemmed flowers and graceful leaves. In the morning the Hadeda Ibis would wake us with their loud melancholic calls. From the forests the melodious call of the Natal Robin could be heard.

It was 1968, in the middle of the swinging sixties. The catchy tunes of the Beetles were everywhere and in our veins ran a strong concoction of hormones from overactive glands. This makes for strong muscles, a zest for life and one-trackminded thinking.

It was during a mealtime that we were discussing the topic that we all knew was true: the government diced the food of all-male institutions like school hostels and soldiers barracks with copper sulphate. This was to diminish their libido and set free more energy for important matters, like studying. It was a well-known fact. However, at our table sat eight intelligentsias, who questioned all beliefs. Is it really true? Wouldn't you see or taste it? And does copper sulphate really affect the libido?

It was our luck that the next day was Sunday. And Sunday night the senior students had their weekly dance. And so we decided to run an experiment. We would add some copper sulphate to the diet of the eight sitting at the table in the corner and observe what happens. Why the corner table? Well, this was to be a random choice, in which you could equally ask: why not? It was also to be a single blind study: we would need to observe what happens, while the research object would have to remain ignorant, otherwise the knowledge would affect their thinking and psychologically affect their libido. How else can you measure the rise and fall of libido? We couldn't think of any other way. This was would be a qualitative study, long before this word was used by researchers. We could ask our subjects afterwards, how they felt at the dance. Meanwhile, we would act as the gold standard: we would presumably be normal and have a good time, as usual.

Our research hypothesis was: $\mathrm{CuSO}_{4}$ dampens the libido and thus the otherwise exciting dance becomes a boring event. We would observe that our research population got bored and abstained from dancing.

We presupposed that $\mathrm{CuSO}_{4}$ is always in our food - so many people say so, that it must be true. This means that a pilot study is not necessary.

We stole some $\mathrm{CuSO}_{4}$ in the chemistry lab. Asking the teacher for some would mean that he becomes a sponsor and this would lead to conflicting interests. The next question was: how much? A pioneer researcher has to be pragmatic. We added a tablespoon to the can of artificial yellow cool drink that we got every Sunday afternoon.

There are always things that crop up in experiments that you don't find in the books. Our research animals seemed to be surprised that the cool drink, which was always daffodil yellow, suddenly was a bright poison green. We observed keenly as they passed the jug around, each sniff- 
ing at it and finally poured and drank the research concoction. The research team sighed a sigh of relief together.

But this was not to be a boring experiment, where everything went according to expectations! Suddenly our whole research cohort got up, ran out of the door and vomited in the courtyard. This was unfortunate! Perhaps we should have broken the anonymity and asked them please not to vomit. But that would have spoiled everything.

So now the teacher came to our table. We thought this unnecessary, because from our point of view, everything was over: the experiment had reached a natural end. But he appointed himself as a one-man ethics committee, coming rather late after the experiment and asking awkward questions:

1. "Are you guys out of your mind?" (We deemed it wise not to answer his questions, but rather to just to look remorseful. But the logical answer here clearly would have been: "No, we would not have reached final exam matric, only reserved for top intellectuals if we were!")

2. "Do you want me to call the police?" (No, no, no, definitely not!")
3. "Did you want to murder your mates?" "What a daft question! We are just researchers, doing what researchers do! We are not murderers")

It was not the end of our experiment. The vomitus made an interesting pattern: bright green on the ochre African soil. Salvador Dali could have painted this, if the smell had not been so disagreeable.

We observed that our subjects all went to bed and were unable to attend the dance. All the members of the research team went and had a great time! Hardly any competition. This is one of the unexpected findings of our study: the nottaking of $\mathrm{CuSO}_{4}$ is good for the libido!

Our long-term follow-up of the unfortunate research rats revealed that their libido was back to normal for the dance a week later. They all passed their matric exams soon afterwards, so there could not have been too much brain damage. And 40 years later most of them are grandfathers! Perhaps $\mathrm{CuSO}_{4}$ increases libido in the long term?

I don't know. And my research career has ended. I am not going to follow that one up, thank you. 